\title{
PARACAS CAVERNAS AND CHAVIN
}

\author{
A. L. KROEBER
}

In a recent review and critique of the Chavín Problem (1), Gordon Willey has listed seventeen ancient Peruvian sites whose remains indisputably affiliate stylistically with the type site of Chavín de Huántar. Beyond the'se, he reviews a greater number of sites for which relationship with Chavín has been alleged. These he puts into three classes: 1, No evidence has been presented for the relationship; 2, There is evidence, but it shows similarities in cultural inventory or context, not of the characteristic Chavín Style; 3, Evidence is available but debatable. In this last class Willey puts the Paracas Cavernas pottery of Paracas and Ocucaje. He sees in its dark-ware, flat-bottomed, incised bowls (2) close similarity with Ancón and Supe Chavín bowls; but this similarity is balanced by the dissimilarities of [a] most of $\mathrm{Ca}$ vernas cerramics being polychrome, and $[b]$ others being negatively painted (3), a technique never or rarely ocurring in a Chavín context. As for an incised and painted fanged cat-face from Ocucaje, (4) it "lacks the characteristis Chavín rendering".

That the similarities to Chavín of the Paracas Cavernas-Ocucaje material "constitute a minority of the total features of the pottery and culture" is something I recognized in 1944 (5). I added that the similarities consist of "occasional sharply specific resemblances, plus a residual sense of kindred quality". Willey and I are thus in agrement that most of the known Cavernas material is not in the strict style of Chavín. We differ in that, with Tello. I see the Chavín minority ingredient as indubitable and significant; he, so negligible as to be doubtful and debatable. This difference of evaluation I wish now to reexamine.

(1) Southwestern Journal of Anthropology (Albuquerque), 7: 103-144, 1951.

(2) Kroeber, 1944, pl. 14 I.

(3) Same, pl. 16 e, g. 1, perhaps $15 \mathrm{~h}$

(4) Same, pl. 13 e.

(5) Same, p. 39. 
But in addition a larger problem obtrudes: What are the stylistic affiliations of the majority ingredients of Cavernas culture if they are not with Chavin? This problem has been slighted because Tello, the discoverer of both Chavín and Paracas as of so many other ancient $\mathrm{Pe}$ ruvian types, was constitutionally far more interested in cultural similarities than in differences. If Cavernas contained a Chavín component, then to him it was Chavín; what the larger remainder of Cavernas might be was something that Tello evidently saw as less important, and hardly discussed. That problem has accordingly lain pretty much fallow since my tentative ruminations about Paracas and Ocucaje in 1944. On account of the physical proximity of the Paracas Cavernas and Paracas Necropolis sites, and of the occurrence at Ocucaje on the Ica River of Nazca culture remains in close spatial proximity to those of Cavernas type, the first analysis must obviously deal with these three; though of course if remoter cultures show resemblances these must also be considered.

First of all, however, let us return to the question of the closeness of sure Chavín similarities in Cavernas-Ocucaje.

1. The strongest Chavin resemblance Willey does not cite: the face design incised on a calabash from Ocucaje (6). This is Chavín all over, the eyes particularly.

2. The incised face on the end of a double-spout jar (7), which Willey says "lacks the characteristic Chavín rendering", seems to me to be, not indeed of the finest Chavin quality, but thoroughly in the style: fangs, mouth, eyes, above all the sweep of line

3. Less pronouncedly Chavín in manner, but definitely within the style, is a profile animal incised on the end of another double-spout (8). It shows nostril roll and seems to have the pupil eccentric.

4. I see Chavín derivation also in the eyes of four other inlaid or modeled vessels from Ocucaje. (9) In two of these the eyes are rectangular; in two, semicircular; in all, the pupil is in contact with the edge or lid -in short eccentric to the eye as a whole- a Chavín characteristic (10).

5. I was able through the courtesy of Sr. Truel to illustrate altogether 38 pieces of the Cavernas -type pottery which he had recovered in Ocucaje by March, 1942. Six of these show the specific

(6) Same, fig. 5 b. p. 40.

(7) Same, pl. 13 e.

(8) Same, pl. $13 \mathrm{c}$.

(9) Same, pl, 13 b, 15 a (rectangular), 14 b, 15 b (half clrcle).

(10) Bame, p. 88. 
Chavín-style resemblances just enumerated. Eleven others are relatively flat-bottomed, more or less vertical-sided, low bowls of heavy, dark ware of a shape found in Ancón Chavín, Supe Chavín, Chicama and Virú Chavín, Kuntur Wasi Chavín (11). Of these eleven bowls from Ocucaje, four are incised (12), six painted (mostly in tre characteristic Cavernas inlay) (13), one is painted either positively or negatively (14). The corresponding bowls at the four compared northern sites appear nearly all to be plain or merely incised, not painted. The unpainted Ocucaje ones are those that Willey admits to be closely similar to those of Ancón and Supe. The painted ones, however, seem thick-walled and may the same unoxidized or uncontrolled ware as the plain ones, with post-firing color inlay or cloisonné added.

This makes 17 of 38 Ocucaje vessels showing Chavin resemblances in one or more traits.

This exhausts the Chavin resemblances in the Truel collection of 1942. It remains to consider resemblances shown by Tello's finds at the Paracas Cavernas type site.

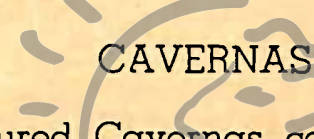

These are the figured Cavernas ceramics actually found at Paracas that have Chavín relations.

1. Tello, 1929, fig. 79, Carrión, 1948, pl. 18, n․ 28. №. 25-4, from Cavern V. Inlaid. Standing, human figurine, perhaps a fish-man. Compare -for the theme, not the style-Carrión, 1948, pl. 19, nos. 4, 5.

2. Tello, 1929 fio 80; Larco 1941 fig. 72; Carrión, 1949, pl. 18, no. 24. No. 2-5956. Modeled head jar. Evidently inlaid. The large tubular neck, of thick ware, slightly convex and with everted lip, is Chavinlike, though there found on stirrup-mouths and long-necked bottles, as in Cupisnique. The eyes are almond-shaped, the pupil a vertical band. There is in this pupil a suggestion of Chavín mannerism about pupils, but no specific similarity. The mouth with everted lip might be Chavín (15). The low nose shows two exposed circular nostrils reminiscent of Chavín (16).

(11) Ancon: Strong, 1925, pl. 48; Ca:rión, 1948, pl. 25, 1-11, 13, 14. Supe: Kroeber, 1925, b, pl. 79 f, g. Chicama: Larco, 1941, flgs. 41,42,64, 65, 74 (painted red and yellow), 76, 77 A (lower left), 79 (several). Kuntur Wasi: Carrlón, 1948, pl. 22, 1-4, 6-9 -Chavín de Huántar, to Judge by Carrión, 1948, pl. 12, lacks the exact type: no. 1 is too hlgh, n?. 3 too incurved, ni. 11 too round-bottomed.

(12) Kroeber, 1944, pl. $14 \mathrm{f}, 15 \mathrm{~J}$.

(13) Same, pl. 13 b, 15 a, d, and probably b; c, $16 \mathrm{f}$.

(14) Same. pl. $15 \mathrm{~h}$. The "polka dots" might be negative; the photograph is Insurflcient for decision.

(15) See Tello, 1929, fig. 22; Carrión, 1948, pl. 10 c, g, h.

(16) Compare Tello, 1943, pls. 21 e, 23; Tello, 1929, fig. 22; Carrión, 1948, pl. 10 d, h, and (Kuntur WasI) pl. 23, nos. 18-20, 24, 28. 
3. Tello, 1929, fig. 81. NN. 12-6319, from Cavern II. Human headand-spout jar, globular, apparently inlaid and of course incised. This piece has little Chavín resemblunce in its modeling, in the form of its incised hands, or in its geometric design, but it resembles the next.

4. Tello, 1929, fig. 82; Muelle and Blas, 1938, pl. 70a; Larco, 1941, fig. 71. Also numbered 12-6319 but from Cavern VI. Very similar to last, except that the modeling and incising show a jaguar rather than a human figure. The pupil looks eccentric in Tello's drawing, less so in Muelle's plate.

5. Tello, 1929, fig. 114; Larco, 1941, fig. 22; Carrión, 1949, pl. 18, 26. № $2-4319$ from Cavern II. Globular head-and-spout with twin heads and forking bridge. Incised, but seemingly not inlaid. The heads are not Chavin-like. The eyes are an oval outline slightly cut off square at the bottom and bisected by a horizontal line. I do not recall this particular effect in Chavin art, but it may be distorted or simplified remiscence of the Chavin habit of having the eyelid half-cover the pupil. The lower half the face design incised on the front of the body of the vessel is definitely in Chavin manner, though somewhat geometric and stiff. The eye in this incised face is a half-almond: arched above, cut off straight and horizontally, below. The mouth is wide and has the canines projecting beyond both upper and lower lips. The idea of a face extending a cross the belly is paralleled in the Chavin Supe crab design in my fig. $5^{\mathrm{a}}$ of 1944

6. Jar with medium-long neck and two side handles, N9. 2-4590, unpublished - if Carrión, 1949, pl.18, fig. 23refers to this piece, the sketch drawing departs from the photograph. Black, incised with mainly rectilinear face design. The mouth has lusked canine teeth; the eye pupil is "eccentric".

7. Recurved bowl, lipless, incised and inlaid (?). "Unpublished, n9. 12-8126. The shape is much like that of Carrión, 1948, pl. 12, fig. 13 from Chavín de Huántar.

8. Low bowl or plate, punch marked. № 12-8983, apparently unpublished. It resembles Kroeber and Strong, 1924, pl. 20, from Huaca Alvarado, Chincha (17).

These detalled similarities of Paracas Cavernas pottery to Chavín ceramics from farther north must be admitted to be somewhat spotty and perhaps more disappointing than those from Ocucaje.

\section{COMPARISON OF SHAPES AND GENERAL TRAITS}

On the other hand, a compilation of the principal vessel shapes and general traits lof all the wares called Chavinoid of which we have

(17) These pleces are reierred to again noto 27 below. 
a good series of examples, reveals at once a number of basic characteristics common to all or most of the sites whose cultures participate in the Chavín style. In addition, such a collocation distinguishes those and traits within the Chavín tradition which are local from those which are universal. For instance, the stirrup-spout is seen to occur at alla northern Chavin sites, but only there. Its place is taken in the far south, in Pisco and lca Valleys, but only there, by the double-spout and headand-spout. In middle Peru, at Ancón and Supe, neither of these ambitious forms has yet been found; the inventory is simpler and is dominated by the bowl shape, which, like incising, is among the universals of Chavín.

The adjoining table summarizes the facts. Very largely, the tubulation has been made possible by recent publications (1948, 1949) of Dra. Rebeca Carrión Cachot, which for the first time provide the needed information on Kuntur Wasi, Chavín de Huántar, Ancón, Paracas Cavernas, Paracas Necropolis en masse. The data in the table on Cupisnique are from Larco, 1941, supplemented by Carrión, 1948 ("Chavín Chicama"); those on Guanape from Ford and Willey, 1949; on Supe from Willey and Corbett, in press in 1951; on Ocucaje from Kroeber, 1944. Paracas Necropolis is outside the Chavín style, but I have added it to the table because of the close topographic proximity of the Cavernas and Necropolis cementeries, and because of the sharing of certain traits - such as the doble-spouted jar - by the two Paracas cultures. On account of the latter fact, I have also included Nazca in the table, although no one considers it as within Chavin culture. -As for the symbols in the table, an asterisk, * denotes ocurrence; $a$ dash-, absence of a feature; a double asterisk, * * signifies that the trait is especially frequent or characteristic; one in parentheses, $\left(^{*}\right)$, that the trait occurs in somewhat different or aberrant form. Where information isolacking, the space has been left vacant.

Before proceeding to discuss the table, I wish to record a simple, homespun observation. Many years ago, when we were unpacking the Uhle collections that had come to California and were setting them in geographic order on shelves, we were driven to notice one distinction that held irrespective of the period of wares. Vessels from northern Peru could simply be put on the shelf and they would sit upright: their bottoms were essentially flat. Vessels from southern Peru had rounded bottoms and neded blocks or props if they were not to tilt or roll over. The north is also the region of the sirrup-mouth, the south of the double spout. These two forms we now known to have persisted in their respective areas hte beginnings of ceramics in the Chavin period as long as native ware continued to be made; much as respective flatness or rounding of base persisted. 


\section{CHAVIN POTTERY}

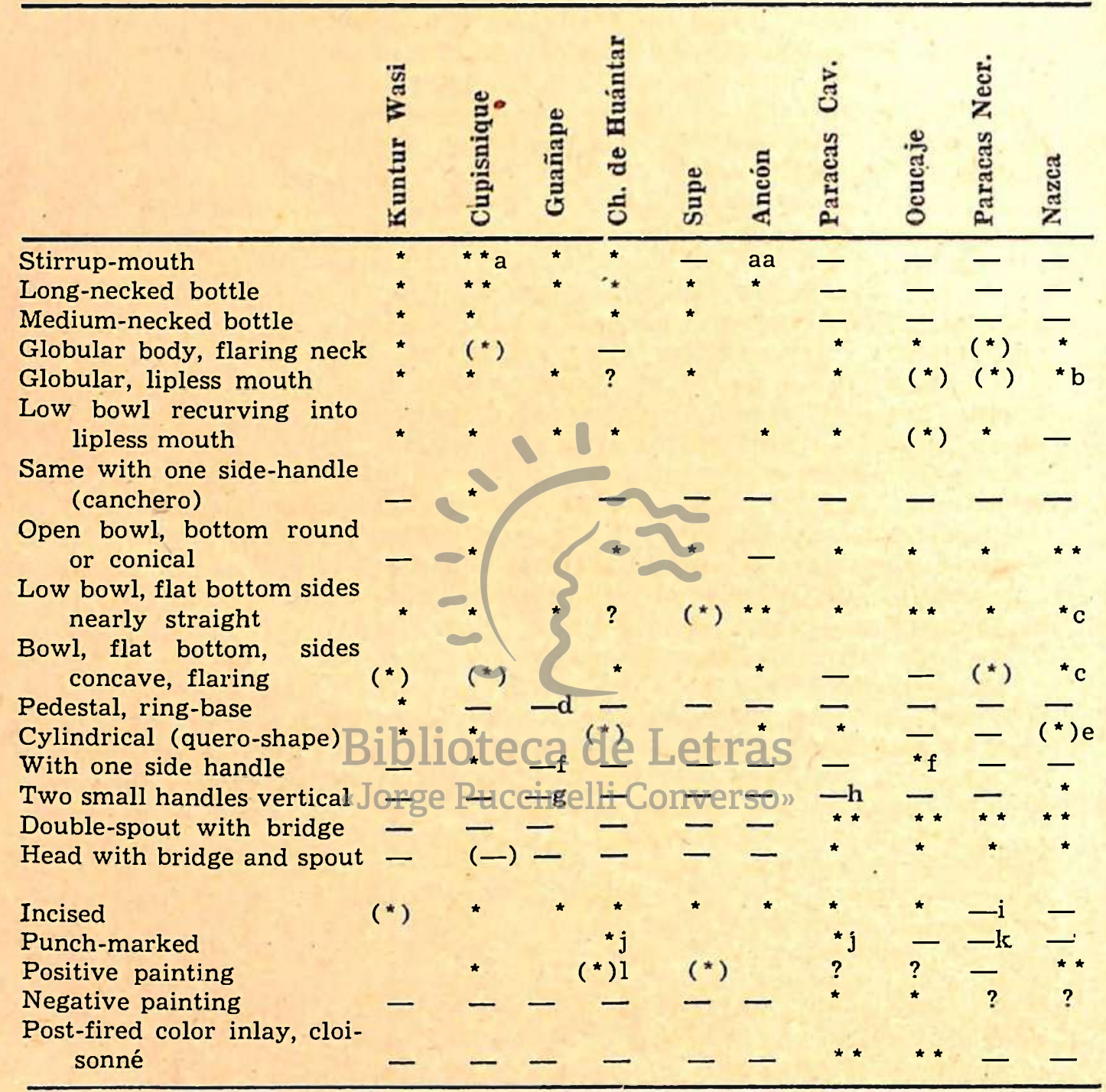

a. Also at Chongoyape to North.

b. Shape Q of see note 35. Gayton and ISroeber, 1927, fig. 2.

c. Nazca bowls only approach flatness.

d. Does not appear in Virú until Gallinazo-Negative.

e. Only in Nazca B, and not true quero profile then.

f. Side handle (strap or tube) to neck spout appears in Virú in Salinar, and at Ocucaje (strap) from broad neck to body.

g. Appear in Virú in Gallinazo-Negative times.

h. Carrión, Paracas, 1949, pl. 18, fig. 23.

i. Vertical grooves to mark panels, no true incising.

$j$. Also at Chincha, Kroeber and Strong, 1924, pl. 20.

k. Fragments occur, may be residue from Cavernas occupation.

1. In incision grooves only. 
The moral is that certain traits of form or features of tradition are independent of the styles characteristic of periods. They cross-cut the styles, persist independently of them, and may endure longer; and yet they may remain regional in the native history of Perú, whereas the styles sometimes have spread far. In the tracing of the history of ancient Peru, it is accordingly necessary to respect both considerations, regional habits and true styles. They must be kept separate until it is clear that they happen to coincide, as they do sometimes.

In the present state of knowledge, it can hardly be doubted that the Chavín style originated in northern Peru. As it was carried into central Peru, to Supe and Ancón, it became somewhat impoverished. On reaching Pisco and lca Valleys, it became reinvigorated and originated or absorbed new features more or less compatible with its original northern manner. This southern revrorked stlye of Cavernas-Ocucaje thus is in part pure Chavín, in part of local origin. After the Cavernas phase ended, its strictly Chavín ingredients disappeared, or were so altered that we can no longer recognize them. But some of the local features - such as double-spouts and-painting- were retained, elaborated, and developed into new styles; namely those of Necropolis and Nazca, in which specific Chavin features are no longer traceable. That is why columns have been adden to the table for these two non-Chavín styles.

Let us now proceed to detailed construal of the tabulation.

\section{ANALYSIS OF TABULATED FEATURES}

Stirrup-mouth.-The northern phase of Chavín style is characterized by the stirrup-mouth both on the coast and inland. We do not know where in the north the form originated, nor under what stimulus. I have thought of an influence of stone carving on Chavin ceramic; Dra. Carrión suggests woodworking. What is most interesting historically is the persistence of the stirrup-mouth form. It was sucessively taken up in Salinar, Negative, Mochica, in all of which luxuriated; it receded in coastal Tiahuanacoid, but revived in Chimú.

Flask shapes.-Te long-necked bottle, and an intergrading medium-long-necked one, occur in the north as well as at Supe-Ancón. Not a single specimen seems to have been found south of these two sites.

Globular body, flaring neck.-A jar with more or less globular body and with a neck of medium length which however flares (instead of constricting or continuing as a cylinder, as in the preceding type), has a spotty distribution, perhaps because it is nowhere very abundant. The reported occurrences are:

Kuntur Wasi, Carrión, 1948, pl. 22, № 16.

"Chicama", same, pl. 13 no. 13; Cupisnique, Larco, 1941. fig. 77, right.

Cavernas, Carrión, 1949, pl. 18, figs. 19, 20. 
Ocucaje, Kroeber, 1944, pls. 15, fig. 14 e (cf. Cavernas fig. 20).

Necropolis, Carrión. 1949, pl. 18, fig. 41.

Nazca, Gayton and Kroeber, 1927, p. 5, fig. 2, S.

While this form occurs in the north, it seems more characteristic of the south. This is in stylistic accord with its globular shape and tendency toward a rounded bottom.

Globular, with lipless mouth.-More widely distributed is a globular or somewhat flattened vessel that keeps curving up and inward to a lipless mouth of perhaps half the diameter of the body. It intergrades with the next shape listed in the table, which differs only in being low enough that it can hardly be called even subglobular. A number of examples are transitional (18), and some are lenticular. Every Chavín-style site possessing a considerable ceramic series shows one or the other form, if not both.

Handled corn-poppers.-On the contrany, the lower or more lenticular of this pair of integrading stapes, but with one conical or cylindrical side-handle added, the canchero or popcorn toaster, occurs within the Chavín style so far as known only at Cupisnique (Larco, 1941, tig. 77, right, fig. 80, lower right, ftg. 66). However, it lasted long beyond Chavín times, ocurring in Negative, Callejón (where it is perhaps most abundant), Mochica, and Proto-Lima. There seem to be no southern occurrences.

Open bowls. - When it comes to open bowls we confront perhaps the commonest Chavin forms. I distinguish those with [1] rounded or conical bottoms from those with [2] essentially flat bottoms, and subdivide the latter into sub-classes [a] with nearly straight sides and [b] those with flaring sides usually somewhat higher. This latter subclass, $2 \mathrm{~b}$, seems lacking at Cavernas and Ocucaje. On the other hand, $2 \alpha$ is heavily represented there, especially at Ocucaje, persisting into Necropoils, and is one of the strongest arguments for linking Cavernas with the northern Chavín style.

Pedestal.-An annular base or pedestal seems to be a peculiarity of Kuntur Wasi without being a trait of Chavin style. It would thus be $a$ local feature which the Chavin style encountered (or developed) there. Three of Carrión's 24 ilustrations show the pedestal (19). The Kuntur Wasi examples are probably the earliest pedestals yet known in Perú. In Virú, the pedesial does not appear till Negative (Gallinazo) times (20). It is abundant in the Callejón, Cajamarca, and Chimú. It occurs in

(18) For Sustance, Carrión, 1948, Chitvin, pl. 12, fige, 13-15.

(19) 1948, pl. 22. 19g. 10, 11, 12 .

(20) Ford and Willey, 1949, 11g. 8. 
middle Cañete, though on low flat bowls only. From Pisco south, it seems never to have got a foothold, whether in the Paracas, Nazca, Ica, or Arequipa styles. Here we have another persistent regional differentium.

Cylindrical goblet.- A cylindrical jar or goblet, quero-shaped, is not abundant but occurs rather widespread.

Kuntur Wasi, Carrión, 1948, pl. 22, fig. 5.

Cupisnique, Larco, 1941, figs. 63, 77 left, 18 top.

Chavín, Carrión, 1948, pl. 12, fig. 8. (base rounded).

Ancón, same, pl. 24, fig. 12, (tapering to top).

Cavernas, Carrión, 1949, pl. 18, figs. 10, 11 .

The Ocucaje sample does not include the shape, neither does Necropolis. Nazca has cylindrical vessels that are taller than high, but only in its later or B phase. Their profile swells, constricts, and spreads again, instead of flaring, and they generally bear crowded designs in bands. The Nazca cylindrical jars should probably not be considered historically related to the quero shape, but as only superficially convergent.

Side handles.- A side handle on a Cupisnique cylindrical vase (21), and another on an olla or lipless incurved bowl (22), may be the earliest cases in Perú of loop handles in a vertical plane. The only other attested Chavin-style occurrence is at Ocucaje, where a broad strap handle loops from the low body of a jar to its broad neck (23). Necropolis and Nazca are entirely without handles, until, in Nazca AB or B, pairs of small suspension handles or perforated lugs appear on one shape of jar (24). Single side handyes do not appear in the Nazca style until the decadent Il phase (25). In the North, the "first post-Cupisnique appearance of a side handle is in Salinar, where Ford in Virú reports a strap or tube handle from shoulder to neck spout (26).

Double-spouts. - Whit the double-spout with bridge, we reach a specialized and characteristic form which is undoubtedly of southern origin within the general Chavín horizon. It is abundant at Cavernas and Ocucaje, and again in Necropolis and Nazca; but it does not occur

(21) Larco, 1941, fig. 63, 77 A left (separate pleces?); Carrión, 1948, pl. 14, figs. 7, 8.

(22) Larco, 1941, fig. 61, $77 \mathrm{C}$ top left.

(23) Kroeber, 1944, pl. $13 \mathrm{f}$, g.

(24) Gayton and Kroeber, 1927, fig. $2 \mathrm{~T}$. The prototype for these may be no. 2-4590 discussed above from Cavernas; and (or?) Carrion, 1949, pl. 18, fig. 23 . There are also occasional three-handled Nazca jars made in rough, unpolished, crudely painted ware. One got by Uhle at Ocucaje is shown in Kroeber and Strong, $1924 \mathrm{~b}$, pl. 28 1. I found one or two in Nazca in 1926. They seem to be utility pleces as contrasted with the funerary ware usual in tombs.

(25) Gayton and Kroeber, pls. 12, 13.

(26) Ford and Willey, 1949, fig. 9. Ford, ibid, records the first paired small handles in Virú Valley as from Gallinazo-Negative period. 
in any other Chavín manifestation, nor in central Peru till White-on-Red, interlocking, and Proto-Lima, or in the nort till Trahunacoid times. It is an obvious counterpart of the stirrup-mouth. In both, there are two tubes leaving the otherwise enclosed body of the vessel. In the one case, these are connected and steadied by a flat bridge. In the other, they are connected and steadied by flowing together into one vertical spout. Technologically, the cardinal point of the invention is likely to have been the manner of the insertion of the two tubes into the body of the vessel. That means, on the principle of economy of interpretation, that we are most likely dealing with one basic invention plus one modification. Since most Chavin traits and sites are found north of Pisco-Ica, the spout style as a whole is far more likely to have developed there than at Cavernas or Ocucaje, and its first use of compound spouts would thus have been in the region of Chongoyape, Kuntur, Chicama, Virú, and Chavín de Huántar. The influence of this invention seems to have been weak at Supe and Ancón, but to have been carried on to Pisco and Ica valleys, where it encountered some activity or skill, perhaps already established, that led to the transformation of the stirrup into the bridge. It seems unlikely that people would have been able to achieve this transformation who were only just learning pottery-making: they would in that case presumably have been content to copy the stirrup-mouth more or less effectively, instead of transforming it. There is thus a suggestion that a pottery art may have been already developed in the Pisco-Ica region when specific Chavín style influences from northern Peru arrived there. It may be worth while to look, for such a culture, which might be as late in origin as the origin of Chavin in the north, but would yet antedate the arrival of Chavinstyle irradiations in the south

The specific local Pisco-Ica antecedents to the impingement would not necessarily have had to be wholly ceramic. They could conceivably have consisted of gourds, gum, and canes (or bird bones as Tello suggested) which established the double-spout shape, that was then retained after pottery-making and the stirrup-mouth were introduced. If the gourds were painted or encrusted with pigments bound by gum or oil or even ciay, this might have served as a model for the unfired inlay or cloisonné that came to be applied to Cavernas and Ocucaje vessels. It is best to keep these conjectures quite tentative, but also to have them in the focus of attention as further explorations are conducted in the area.

Double-spouts, raggedly made and almost laking in style, begin to appear scatteringly in Chancay White-on-Read, continue into Interlocking, and become more frequent and somewhat better in quality in Proto-Lima. By Tiahuanaco times they have attained a new characteristic shape at Pachacamac and Ancón (as well as in Nazca): flattened body, tapering spouts spreading apart, a humped bridge, Tiahuanacoid painted design. Muelle has made a plausible case for this modified form being the result of development in sheet metal, then retransferred to clay. This new double-spout reached the northern coast in Tiahuanacoid times, tending to displace the native stirrupmouth. It maintained itself until Spanish times, although with the Chimú the vogue of the stirrup revived. 
On the other hand, the stirrup-mouth never did penetrate the south. In the Late period it seeped as far as Lima Valley, most often in blackand-white or black-white-red Chancay or sub-Chancay tradition; but not regularly beyond.

So much for the interesting history of these two related forms.

Head-and-spout.-It still $r \in$ mains, however, to consider another form obviously related to the double-spout, namely the head-bridge-andspout, in which a human, animal, or bird head "replaces" one of the two spouts. This looks like a derivative from the pair of unfigured spouts. The distribution in our tabulation confirms the conjecture. The head-andspout occurs in the same cultures as the double-spout, though less abundantly: Cavernas. Ocucaje, Necropolis, Nazca.

There is a second distribution of head bridge-and-spout vessels that seems to be separate from the present one, and is in fact outside the Chavin tradition. It is post-Chavin in period and it occurs in northern instead of southern Peru and in the highland as well as on the coast. It will be discussed separately below.

We come now to surface treatment in the Chavín style.

Incising.-This is of course the characteristic method of Chavin decoration. It is universal. Its lack from Necropolis and Nazca marks these two manners as perhaps partly Chavin-derived but no longer within the Chavin style. Necropolis occasionally shows vertical grooves that separate swelling panels; but such grooves are part of the basic shaping, not superstructural incising. Nazca of course replaces incisions by polychrome painting. It is there-fore remarkable that Necropolis wholly lacks both incising and paint.

Punch-marking.- While the basic Chavin method of incising is with a heavy, flowingoline, thereiare lalso various ways of scoring or roughening the surface or adding buttons or other appliqué. The recent Carrión publications assemble convenient sketches of most of these methods. I am here singling out one particular method of roughening because it brings an additional valley into the Chavin range, namely Chincha. I have previously commented on the resemblance of certain shallow, conical bowls from Cavernas to fragments dug by Uhle in the Huaca Alvarado in Chincha (27). The punching is diagonal to the surface, the impressions almost cuneiform.

Positive Painting.- $\AA$ small minority of characteristic Chavín vessels are painted as well as incised. Larco has assembled the greatest number from Cupisnique (28), and subsequently has put them into a late sub-period of Cupisnique (29). For the name site, Carrión mentions

(27) Kroeber, 1944, pp. 34-35, pl. $41 \mathrm{~b}$; Kroeber and Strong, 1924 a, pl. 20 . See note 17 above. - Pl. 12, fig. 10 of Carrión, 1943, from Chavín de Huántar, is similar except for the wide spacing of the single impressions. Her 1949, pl. 18, fig. 17 from Cavernas is less similar, both in vessel shape and in regularlty of the seemingly almost vertical punch marks. The fragment from Supe in Kroeber, $1925 \mathrm{~b}, \mathrm{pl} .79 \mathrm{~J}$ is somewhat similar.

(28) Larco, 1941, figs. 38, 40, 48.

(29) Larco, 1948, pp. 18, 19. 
only occasional painting in the incisions grooves (30). At Supe, Uhle found at least one sherd that was red-painted within incision-bordered areas (31). For Ancón, Carrión is silent. For Ocucaje, I am in doubt and at fault: owing to lack of time. I failed to supplement with written notes the photographs authorized by Sr. Truel (32).

By contrast, the efflorescence of polychrome painting in Nazca is very marked, especially in view of the fact that the other post-Chavin culture of the area, Necropolis, seems wholly to lack painting on pottery as well as incising.

Negative Painting.-This is characteristic within the Chavin tradition only at Cavernas and Ocucaje (33). Farther north, negative or reserved painting is characteristic of post-Chavín horizons: White-on-Red and Interlocking, Recuay, Virú-Gcrllinazo. This is one of Willey's reasons for essentially excluding Cavernas and Ocucaje from the Chavin style (34). However, the conflict is in the criteria used to define our classifications, not in the styles themselves: There is no doubt of the fact that negative painting occurs in association with Chavin design at the two southern sites.

Cloisonné.-Post-fired color inlay is also characteristic of Cavernas and Ocucaje - and only of them in all Peru, so far as known. There is no trace of it at Necropolis that adjoins Cavernas at Paracas, nor in any phase of the Nazca style whose remains adjoin the Cavernastype remains in the oasis of Ocucaje. The isolation of the phenomenon leaves it unexplained. What there is need of, while discovery of related or identical techniques elsewhere is being waited for, is microscopic examination and chemical determination of the "cloisonne" material and process.

\section{"Jorge PuUMMAâRYConvérso"}

This analysis of ceramic traits and their distribution shows that at least three local phases must be recognized within the Chavin style and culture. The northern is characterized in pottery by stirrup mouthsalso by a tendency to sculptural modeling in clay and in the highland in stone. The central sphere to date is known from Supe and Ancón and seems to lack spouted vessels of any kind (35), as well as affigy modeling. The southern province is characterized by substitution of double spouts and head-and-spouts for stirrup-mouths. It possesses some modeling, negative painting, and cioisonné inlay.

(30) Carrión, 1948, p. 39

(31) Kroeber, $1925 \mathrm{~b}$, pl. $79 \mathrm{~h}$.

(32) Kroeber, 1944, pl. $15 \mathrm{~h}, 16 \mathrm{f}$. look negatively painted but may be positlve.

(33) Kroeber, 1944, pl. $16 \mathrm{a}, \mathrm{e}, \mathrm{g}, \mathrm{l}$, apparently also $16 \mathrm{~J}, \mathrm{k}$, perhaps $15 \mathrm{~h}, 16 \mathrm{f}$-from 4 to 8 vessels out of 38 . It is possible tlat negative palnting carried over from Cavernas into some phases of Nazca. See Kroeber, 1944, pp. 36, 117.

(34) Willey, 1951, p. 132.

(35) Strong, Wllley, and Corbett, 1943, p. 16, report but do not llustrate "one excellent fragment from stirrups-mouthe Jar... found one of the test pits". 
While the center of gravity of the Chavin culture undoubtedly lay in northern Peru, and Cavernas-Ocucaje is its most southern known mafestation, it does belong within the culture, though it also does contain elements lacking in the north and center. It may be somewhat later; but there is nothing to show that it was markedly later than the Chavin of Chicama, Virú, and Huántar. The most parsimonious interpretation is that it was only as much later as it took substantial elements of the north Chavín culture to be carried and introduced to Pisco and Ica valleys.

\section{NECROPOLIS AND NAZCA}

In distinction from Cavernas and Ocucaje, Necropolis and Nazca contain no clear Chavín traits, though they carry on certain CavernasOcucaje specialties, such as double-spouts.

I think therefore that there can no longer be any question that the Cavernas culture was earlier than both Necropolis and Nazca.

As to the time relation between these two latter, I hesitantly once advanced the theory that Nazca, or at least its beginning, the $\mathrm{A}$ phase, preceded Necropolis (36). This was largely on the ground that Necropolis embroidered designs were more likely to be based on the similar Nazca painted pattery designs than the reverse.

I am more dubious of this hypothesis than I was seven years ago. On the other hand, I see no specific reason which demands putting $\mathrm{Ne}$ cropolis earlier than Nazca. The close physical collocation of the Cavernas and Necropolis cementeries at Paracas might suggest a close connection in time also, but by no means proves it. At Ocucaje, the Cavernas-type remains occur topographically just as near to Nazca $A$ and Nazca B (37) remains.

I had hoped"that the tabulation, which in the preceding pages has been analyzed for its relations internal to Chavín, would extrapolate so as to indicate either Necropolis or Nazca as agreeing in definiteil more features than the other with Cavernas-Ocucaje. But the results are for from decisive.

Nazca more similar to Cavernas-Ocucaje (as per table) 'Globular jar with flaring neck.

Low bowls with bottom rounded or conical.

Cylindrical jar (but Nazca has no true quero shape).

Two small vertical handles on shoulder.

Necropolis more similar to Cavernas-Ocucaje

Low bowl curving into lipless mouth

Low bowls with flat bottom and straight sides.

(36) Kroeber, 1944, p. 34.

(37) The Nazca-type collections frovi Ocucaje described by Kroeber and Strong in thelr Ica papel, 1924b, are the type collection for Nazca A. But Ocucaje also has Nazca $B$ sherds in abundance on the surface-womens yellow faces in patterned rows, etc. This is my personal observation in 1925 and 1926. 
Nazca.

This does not seem a conclusive preponderance for priority of

On the other hand, there are certain specific similarities in design between Uhle's Nazca A collecticn from Ocucaje and the Truel Cavernas-type collection from Ocucaje (38). They are significant because the material is from the same "'oasis" and because Nazca $A$ is assumed to be the earliest form of Nazca. The resemblances list as follows:

\section{Ocucaje Nazca $A$}

Pl. $25 a$
$26 a$
$26 j$
$27 o$
$26 e, 27 c, 28 f$
$27 e$
271
$28 m$

Man-figure jar
Bird
Bird
Bird
Diamonds
Checker
Step (-fret)
Face

Truel "Ocucaje"
Cavernas
Pl. $14 b,(13 a)$
$15 e$
$14 e, 15 d$
(?)
$14 f, 15 f$
$16 f$
$15 g$
$15 b, 12 a$

The human-figure jars eare not too similar, except in general idea, and this resemblance should not be pressed. All the other resemblances are in design, pigment-painted in Nazca, usually inlay-painted (cloisonné) in Cavernas but also incised.

In the first of the birds there is, on both sides, a long beak, a long deeply-looped neck, a long wing separated from the body a cleft. The second Nazca bird, 26j, has the beak pointing downward, and a band across the base of the tail. This banding recurs in both the Cavernas counterparts, and the llowered beaklin 15d.OITherthird Nazca bird, 27o, and several humming birds, have no precise Cavernas equivalents.

The diamonds or erect rhomboids are in a continuous row in Nazca, free-standing in one Cavernas equivalent, contiguous in the other. Erect diamonds are not common in Peruvian design on pottery; usually they lie. The two checker-covered bowls are strikingly similar. The step is accompanied by a fret in Nazca, not so in the Truel piece; but there is an impression of similarity, due to thin-line borders or incisions.

The faces are done in difierent stylistic manners, but agree in each having two vertical lines below the eyes and in two long locks or loops curving from the top of the head down past the cheeks on each side. The principle of the designs, their theme, is markedly similar once it has been recognized. The motive recurs in the Cavernas-Ocucaje painted cloth of plate $12 a$.

These resemblances are all in minutiae, it is true, but some of them are quite specific and would, even if unsupported, go far toward establishing some historic connection between the two wares, in spite of their technological and stylistic difference.

(38) Kroeber and Strong, 1924b, pls, 25-29; Kroeber, 1944, pls. 12-16. 
Necropolis pottery, unfortunately, is without designs, so can have no corresponding similarities with either Cavernas or Nazca. The cited Nazca-Cavernas resemblances therefore prove nothing as to the time order of Nazca and Necropolis. They do establish that Nazca evidently followed on Cavernas after a not too great interval, though long enough for one style to be superseded by a quite distinctive one.

Reviewing with closer cornparison the publications on Cavernas, Necropolis, and Nazca textiles by Carrión and O'Neale (39), I now conclude that all three arts are basically close together. I would no longer group Cavernas and Nazca as contrastable with Necropolis, except in what might be called quantitative weighting of processes. Necropolis embroiders much more lavishly than the others. But Nazca embroideries technically match those of Necropolis, except for being fewer, smaller, and less sumptuous. This difference may well be one of economics rather than of textile skill. And in weaving proper as distinct from embroidery, all three arts run closely parallel.

In pottery, the interlocking fish or snake pattern, which inevitably suggests a textile origin, appears in the later or B phase of Nazca. But its hitherto overlooked textile antecedents, so far as reported, occur in Cavernas, as Carrion's important illustrations show (40). This might seem to indicate a juxtaposition in time of Cavernas and Nazca. But if so, it would put late Nazca near Cavernas; and since on account of the total absence of outright Chavín features Nazca cannot be put before and must be put after Cavernas, we have two alternatives left. Either Nazca B was not late but early Nazca, as Tello always contended (he called it Pre-Nazca); which I cannot believe because the drift between the two phases seems to me stylistically construable in one direction only. Or we are driven to the explanation that the interlocking fish pattern of Cavernas textiles fequired the duration of Nazca $A$ for its transfer into pottery painting in Nazca B; which is a possible view, but a speculative one.

$\mathrm{Y}$ think what we must admit is that we must await further evidence before deciding positively as to the time order of Necropolis and Nazca-in fact also, possibly, to the precedence of Nazca A and B (41).

It is evident that ceramics were much less stable in style than textiles in this southern area in early times. Some of the basic shapes of Cavernas continued; but its incising was last in both Necropolis and Nazca; its inlay painting and probably negative painting were also lost in Necropolis but replaced by positive painting in Nazca.

The two successor styles differ markedly in one regard. Necropolis is known to us only as sharply localized at one site in one time.

(39) Carrión, 1931; O'Neale, 1937; O'Neale and Kroeber, 1930.

(40) Carrión, 1931, fig. 2 p. 41. -See also Yacovleff and Muelle, 1934, p. 141, fig. 26. g (Cavernas weaving, not necropolis embroldery).

(41) It is of course conceivable that Nazca A of Ica Valley represents a local variety of Nazca as well as a time phase, or that it represents a local varlant even more than a temporal one. However, I do not conside: the latter llkely, because all or most Ica Valley types of Nazca ware found also in Nazca Valley. - I may add that I consider the Gayton and Kroeber 1927 classification of Nazca ceramics into $A, A B$ or $X, B$, and $Y$ essentially 
Nazca is all over Ica and Rio Grande Valleys in its presumably early and mature $A$ and $B$ forms, and in its decadent and mixed $Y$ phase it spread south to the Majes, north to Cañete, inland to Huari (42). Necropolis certainly looks like an end about to die; Nazca clearly ran a long and varying course and left wide influences if not direct issue.

\section{APPENDIX}

\section{Northern Head-Bridge-and-Spouts}

I return now to the second and semi-autonomous distribution and history of head-bridge-and-spout vessels in Peru. This currents is postChavín instead of Chavin in origin, and primarily northern instead of southern. It also includes certain forms not characteristic of Paracas and Nazca head-and-spouts. The occurrence falls outside of our tabulation: in Salinar, Virú-Negative-Gallinazo, Recuay, Wilkawain in what might be called early. post-Chavín times, and subsequently in HuariTiahuanacoid, Lambayeque-Abigarrado-Cursive Modeled, and Chimú and Chimoid.

In this northern form, the head may be replaced by a bust or halffigure, or by a whole figure, and this may be human, mammal, bird, or even plant. These variations seem to be secondary. But a distinction must de made between 1) single vessels bearing the head-bridge-andspout and 2) double-chambared vessels ("double jars") of which one bears a head or is a figure while the other bears a spout, these upper elements being then connected (originally for structural strength) by $a$ non-tubular bridge, in addition to the invisible opening connecting the two chambers below. The second type results very easily as an elaboration or by-product of the basic two-chamber form, especially if one of these is shaped as an effigy. In the single-chamber or single-receptacle type, however, the head-bridge-and-spout complex is not suggested by the basic form, but is deliberately imposed on it.

\footnotetext{
sound, but now belleve that we might have classified with more precision if, instead of dejeuuiing primarily on a shape-design correlation, we had frankly regarded the OcucajeIca Nonga collection of Uhle as a "pure lot sample" which defined A (less possible mluor regional variation), and head then defined $A B$ and $B$ flrst of all by subtracting the $A$ types from the large collection of mixed $A, A B, B$, and $Y$ which Uhle had obtained in the Rio Grance Valley largely by purchase from huaqueros, with excavation of only a very few graves by himself. However, the present recognition means only that hindsight is often the better, and $I$ am in no sense repudiating our 1927 classification, merely suggesting that It can be corrected in detall.

(42) Nazca shares its characteristic gray pigment with Classical Tiahuanaco, Coast Tiahuanaco, and Huarl. This gray is so uniform that it is surely due to one particular mineral constituent, wherever and whenever it occurs. The ceramic styles using the pigment are therefore hlstorically connected by $1 \mathrm{t}$; and Nazca $A$ appears to be the carliest of them.
} 
With one or two exceptions atributed to Cupisnique (43), the earliest examples of the single-chamber head-bridge-and-spout seem to be in the Salinar culture of the roorthern Coast with which Larco's little monograph of 1944 has made us familiar. Salinar is a stirrupmouth ceramic which however also employs the figure-bridge-and-spout complex. When there are two figures or chambers, they are connected by a stirrupmouth (44); the bridged forms are all single-chambered (45). In the collection which I inspected in the Larco Museum at Chiclín in 1942 , about 10 per cent were bridge-and-spout (46). The human exemplars vary from a head to a half-figure to a full figure (47); sometimes the figure is a bird, or a plant something like a cactus (48). Some of the figures look across the bridge at the spout (49), in contrast with the normal arrangement in nearly all post-Salinar cultures, where the spout rises behind the head or person. This inward-facing position seems the result of indeterminacy during the groping, formative phase of this style element.

Larco has also illustrated three figure-bridge-and-spout vessels as being Virú-Cupisnicoide ( 50 ). The is a Virú Valley variant of Cupisnique, probably later than Chicama Cupisnique, perhaps of a period equivalent to Salinar in Chicama Valley. At any rate the three vessels in question are very similar to the more numerous Salinar figure-bridgeand-spouts just discussed, in body-shape, spout, half-length human figure, sharp nose on this, facing toward as well as away from the spout (51). And the one Virú-Cupisnicoide "phytomorph" is in its general

(43) One of these pre-Salinar pleces is Cupisnique in Larco, 1941, fig. $77 \mathrm{C}$ rlght. This is a two-chambered vessel representing what is probably a dog, with a spout rising out of its haunches. No photograph of this plece seems to have been published, and the outline drawing does not seem very Chavin-like in style. Confirmation from other, similar exampleg is therefore desirable to make sure there has been no error of attribution or record. -The second specimen was lound with the Chongoyape/gold, and while therefore generally credited with Chavin-Cupisnique affiliation, it is aberrant. The vessel is singlechambered, cylindrlcal-lenticular. From 1 ts top, near the edge rlses a modeled erect animal figure, or half-figure, perhaps of a rodent, facing outward. From the animal's neck there issues not a bridge but a short tube that joins a longer curving one which rises from near the opposite edge of the top of the maln body the vessel. On joining, the two tubes rlse in a typical Cupisnique spout. What we have, then, is really a typical stirrupmouth except for tha abnormality that the base of one of its tubes is replaced by a modeled figure; but this figure is quite similar to those of Salinar figure-bridge-and-spouts. The plece accordingly is hybrid in type; or,historically, it looks like an undifferentiated stirrup-mouth-figure-an-spout. - Nelther of these presumably Chavinoid specimens thus fully anticipates the standart single-chambered figure-bridge-and-spout of Salinar: the first is double-chambered, the second lacks a bridge.

(44) Larco, 1944, figs. on pp. 2, 3, 4.

(45) Larco, 1944, pp. 9, 10, 11 top.

(46) Kroeber, 1944, p. 56.

(47) Larco, 1944, pp. 5, 9.

(48) Same, pp. 10, 11, top.

(49) Same, p. 5, middle row, p. 9, right.

(50) Larco, 1941, figs. 43 (two on left), 70; first two also in clearer outline drawing in fig. $80 \mathrm{~A}$, top left. In Larco's publications of 1945 and 1348 the term Viru-Cuplsnicolde is no longer used.

(51) In fact, 1941, fig. 43, second irom left, might be, so far as the reduced photographs allow Judgment, identical with Sallnar, 1844, p. 5, row 2, second from right, excopt for the broken tip of the spout of tho latter. 
shape $-a$ bud, bulb, or swelling shoot or fruit- much like the Salinar "cactuses".

We next come, in time seuuence, to Virú, as Larco has renamed his former Negative and Bennett's Gallinazo. Hare, in contrast with Salinar, we encounter not only single-chamber but double-chamber figureand-spouts. Larco shows four of the single and two of the double type, besides a double one of the Virú style of Chicama Valley, which he construes as later (52). Bennett figures one and two examples respectively (53).

Like Viru, the Recuay style of the Callejon de Huaylas uses negative painting. There are other resemblances, and the two cultures may be contemporaneous. Bennett shows both single-chambered (54) and double-chambered, spouts from Recuay (55). Bennett also has classified 357 Recuay-style vessels from 8 collections. These contain 79 single-chambered and 22 double-chambered figure-and-spouts, 49 of the former and 10 of the latter with three-color negative painting (56).

It is clear that the figure-bridge-and-spout device is strongly represented in post- Cupisnique, pre-Mochica northern ceramics -on top of single- chambered vessels in Salinar, on both single and double in Virú-Gallinazo and Recuay.

By contrast, it goes out almost wholly in Mochica - a style which channneled and reduced the number of its basic shapes- except for rather rare though well-made double-jars (57). In these the figure-andspout idea seems incidental to the double-chambering.

After Mochica times, the figure-bridge-and-spout was again made in northern Peru, notably in Coast Tiahuanaco (Huari-Norteño), HuariLambayeque (Abigarrado, Cursive Modeled) and Chimú. It occurs there in single and double-chambered form; and clongside the non-figured double-spout, which was the old dominant spouted shape in the south in Chavín and Nazca times and which seems to have been carried to the north by the stream of Tiahuanacoid and Huari influences. After the first surge of this in the north weakened, the original northern stirrup. mouth revived in favor, and in Chimu times it is reestablished (both in old Mochica territory and north thereof, and to some extent to the south as far as Chancay and Lima) almost as prominently as in Mochica
days.

(52) Larco. single-chambered: 1945, j: 5 top right (figure on caballito raft. looklng Inward); p. 5 , bottom right (glso 1848 , n. 23 , second from right), slarimp with spoist snd bridge from neck of animgl box (two figltes on a single chamber!); p. 7, tols, lying (iecr. also 1948 , p. 5, lower left, to sumit out of rump: 1948, p. 23, third from rlglit; posslbly left), drummer; 1948 , p. 23, second foub-chnmbered: 1945, p. 4 (also 1948, p. 23, thlect from spouted.

(53) Benmett, 1939: slngle-chamberet, fig. 13 j. on pedestal; doulble-chambered, flgs.

14 e. 13 g (this last has four pear-shaped receptacles).
(54) Bennett, 1944, fig. 32, Hi, H-3: also types H-3.

(55) Same, Iff. $32 \cdot I-1$, and $p$. 102 : also types H-3, H-4, D. 102.

(56) Same, pp. 99, 103.

(57) Kroeber, $1925 \mathrm{R}$, pl. 56, k. l. Thev constitute only 2 out of 594 vessels in the Uhle Mochica collection. 
Proto-Lima has been omitted from this review of northern spouted forms because its spouts seem to have been derived mainly from the south. The simple double-spout exceeds the ifgure (or head)-and-spout by 6 to 1 in Gayton's published Nievería material, and by 15 to 5 in d'Harcourt's "Cajamarquilla". The stirrup-mouth is lacking. The style which precedes Proto-Lima, Uhle's Interlocking at Chancay, shows double-spouts (58). In the Chancay White-on-Red that precedes Interlocking, there is one clear case of a double-spout (59) and a marginal one of a bird head-and-spout (60). - As for Proto-Lima, northern influence are not wholly lacking in the ceramics of this culture (61).

Middle Cañete has both plain doublge-spouts and single-chambered head-and-spouts that show more or less late Nazca (B) influence (62). Cañete being more or less half-way between the Nazca area of Ica and as gateway for the northward transmission of Nazca influences to Interlocking and Proto-Lima; and its spouted ware looks transitional between the two. It is at any rate out of the northern head-bridge-andspout current.

The main facts are all so familiar that they need not be substantiated by further citations. They are reviewed as the concluding chapter in the complex history of interrelations of the stirrup-mouth, the double-spout, the single-chambered figure (or head) and spout, and the double-jar or two-chambered form of this. All of these are typologically related by being based on the element of the tubular spout. They are also undoubtedly related historically. As the foregoing paragraphs show, the interrelations are fairly complex, but there is now enough temporally placed evidence available to make the cutline of events fairly clear.

\section{Biblioteca de Letras "Jorge Puccinelli Converso"}

(58) Kroeber, 1926, pls. 88 a, 89 f.

(59) Kroeber, 1926, pl. $86 \mathrm{f}$.

(60) Same, pl. $86 \mathrm{~g}$.

(61) Compare the Mochlca-Influenced effigy vessels in Gayton, 1927, pls. 92 a, b, 95 g. $h$, and the corn-poppers of pl. 95 a, c. r.

(62) Kroeber, 1937, pl. 70, fig. 2, pl. 73, flgs, 1, 2, 3 (clouble-spouts); pl. 73, fig. 4 (figure-and-spout); see also for two of these Bennett, 1946, fig. $12 \mathrm{c}$, e. 


\section{WORKS CITED}

Bennett, W. C., 1939. Archaeology of the North Coast of Peru. Anthr. Pap. Am. Mus. Natural Hist., 37: 1-153.

1944. The North Highlands of Peru. Same, 39: 1-114.

1946. The Archeology of the Central Andes, pp. 61-147 of Bur. Am. Ethnol. Bull. 143, Handbook of S. Am. Indians, 2: The Andean Civilizations.

Bennett, W. C., and Bird J. B., 1949. Andean Culture History. Am. Mus. Natural Hist., Handbook Series No 15.

Carrión Cachot, Rebeca, 1931. La Indumentaria en la Antigua Cultura de Paracas. Wira Kocha, 1: 37-86, pls. 1-2, figs. 1-22.

1948. La Cultura Chavín: Dos Nuevas Colonias: Kuntur Wasi y Ancón. Revista del Museo Nacional de Antropología y Arqueología, 2: 99-172, pls. 27, figs. 20.

-Also issued as separate, with ill. cover, title page, and contents, paged $1-80$ (p. 7 corresponding to p. 99), and two unnumbered pp. of bibliography added.

1949. Paracas: Cultural Elements. Publ. by Corporación Nacional de Turismo, Lima. Pp. 1-62, P1s. 1-23 (plus col. frontispiece), figs. 1-7.

Ford, J. A., and Willey, G. R., 1940. Surface Survey of the Virú Valley, Peru. Am. Mus. Natural Hist., Anthr. Pap. 43, part. 1, pp. 1-90.

Gayton, A. H., 1927. The Uhle Collections from Nieveria, in Univ. Calif. Publ. in Am. Arch. Ethnol., 21: 305-329.

Gayton, A. H., and Kroeber, A.LL, 1927. The Uhle Pottery Collections from Nazca, in Univ, Calif. Publ. in Am. Arch Ethnol., 24: 1-46.

Kroeber, A. L., 1925a. The Uhle Pottery Collections from Moche, in Univ. Calif. Publ. in Am. Arch. Ethnol., 21: 191-234.

1925b. The Uhle Pottery Collections from Supe, in same, 21: 235-264.

1926. The Uhle Pottery Collections from Chancay, in same, 21: 265-304.

1937. Archaelogical Explorations in Peru, Pt. IV, Cañete Valley, in Field Mus. Natural Hist., Anthropology Mem., 2, No 4.

, 1944. Peruvian Archaeology in 1942. Viking Fund Publ. in Anthr., No 4.

Kroeber, A. L., and Strong, W. D., 1924a. The Uhle Collections from Chincha, in Univ. Calif. Publ. in Am. Arch. Ethnol., 21: 1-54.

1924b. The Uhle Pottery Collections from Ica, in same, 21: 95:133.

Larco Hoyle, R., 1941. Los Cupisniques. Lima, 259 pp.

1944. Cultura Salinar. Trujillo, $20 \mathrm{pp}$.

1948. Cronología Arqueológica del Norte del Perú. Trujillo, $87 \mathrm{pp}$.

Muelle, J. C., and Blas, C., 1938. Muestrario de Arte Precolombino, en Revista del Museo Nacional, Lima, 7: 161-280. 
O'Neale, Lila M., 1937. Textiles of the Early Nazca Period. Field Museum of Natural History, Anthr. Mem. II, No 3, pp. 121-208, pls. 32-68, 1 fig.

O'Neale, Lila M., and Kroeber, A. L., 1930. Textile Periods in Ancient Peru. Univ. Calif. Publ. Am. Ethnol., 28: 23-56.

Strong, W. D., 1925. The Uhle Pottery Collections from Ancón, in Univ. Calif. Publ. in Am. Arch. Ethnol., 21: 135-190.

Strong, W. D., Willey, G. R., and Corbett, J. M., 1943. Archeological Studies in Peru, 1941 - 42. Columbia Studies in Archeology and Ethnology. vol. 1.

Tello, J. C., 1929. Antiguo Perú; Primera Epoca. Lima. 183 pp., 6 pl., 115 figs. 1943. Discovery of the Chavin Culture in Peru. Am. Antiquity 9: $135-160$.

Willey, G. R., 1949. "Ceramics", in Bur Am. Ethnol., Bull. 143, Handbook of South American Indians, 5: 139-294, pls. 29-40, figs. 42-63.

1951. The Chavin Problem: a Review and Critique. Southwestern Journ. Anthr. 7: 103-144.

Yacovleff, E., and Muelle, J. C., 1934. Un Fardo Funerario de Paracas. Revista del Museo Nacional. Lima, 3, No 1-2: 64-163.

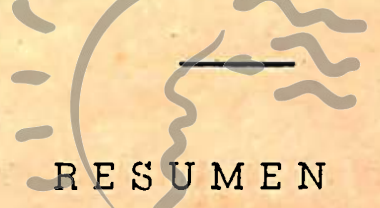

En un trabajo reciente sobre "El Problema de Chavín", Gordon Willey enumeró 17 sitios arqueológicos con restos que están relacionados estilísticamente con la estación-tipo de Chavín de Huántar. Además de éstos, revisó un número máyor de lugares a los cuales se les ha atribuído la misma relacion, y los clasificó en tres grupos: 19.-Aquellos para cuya relación no se ha presentado evidencia; $2^{\circ}$-Aquellos que tienen evidencia, pero que muestran semejanza en contexto o inventario cultural, más bien que en el característico estilo chavín; 3:-Aquellos que tienen alguna evidencia, pero discutible. En este último grupo ha colocado Willey la cerámica de Cavernas de Paracas, y de Ocucaje, y ha visto en sus tazas negras incisas una semejanza estrecha con las tazas chavín de Ancón y Supe, aunque vió también diferencias: los cerámicos de Cavernas son palicromos, en su mayoría, y otros son de pintura negativa, rasgos que no encontramos en el contexto chavín.

El Prof. Kroeber analiza en este trabajo sus discrepancias con Willey, con quien concuerda en que lo conocido del material de Cavernas no es total o estrictamente de estilo chavín, y con quien discrepa al conceder significación a ese pequeño margen de ingrediente chavín, que Willey estima despreciable, dudoso y debatible.

Kroeber examina también otro problema relacionado con la cuestión anterior: Si la mayoría de los ingredientes de la cultura de Cavernas no es chavín, ¿cuáles son sus conexiones estilísticas?

En seguida, el autor pasa al análisis de las relaciones con Ocucaje, Necrópolis de Paracas y la cultura de Nazca. Compara las formas y 
rasgos generales de todo el material denominado chavinoide llamando la atención hacia la distinción de las características locales, como el gollete en forma de estribo, que no aparece sino en el Norte, y las características que él llama universales o comunes a todos los sitios chavín.

Kroeber cree que, al presente no se puede dudar de que el nacimiento del estilo chavín se ha oriạinado en el norte del Perú y que pasó después a Supe y Ancón, donde degeneró algo. Y que cuando llegó a Pisco e lca se revigorizó con la cadición de otros rasgos: aquí se originaron entonces el estilo de la Necrópolis y el de Nazca.

En seguida revisa los caracteres más importantes, que ha colocado en un cuadro; gollete-estribo, forma de frasco, cuerpo globular y cuello expandido, globular con borde sin labios, canchero con mango, tazas abiertas, pedestal, vaso cilíndrico, asas laterales, doble pico, cabeza y pico, incisiones, marcas de punzón, pintura positiva, pintura negativa, cloisonné.

Las conclusiones a que el autor llega, después de estudiar los rasgos y su distribución, muestran pues tres fases locales en el estilo cerámico de la cultura chavín: la del Norte, con gollete-estribo y tendencia escultórica; la del Centro, en la que no hay modelado ni pico de ninguna clase; y la del Sur, que ha reemplazado el estribo con el doble pico y la cabeza pico, que tiene pintura negativa, cloisonné y algo de modelado.

Ocucaje y Cavernas son la manifestación más meridional del estilo, y pueden significar una etapa tardía, pero nada hace presumir que lo sea más que chavín de Chicama, Virú y Chavín de Huántar.

Necrópolis y Nazca no contienen rasgos chavín, aunque sí ciertos otros caracteres de Cavernas y Ocucaje, comoel doble pico. Por lo tanto, Kroeber piensa que la cuestión de prioridad cronológica está resuelta en favor de Cavernas.

Kroeber había expresado una vez la opinión de que la fase $A$ de Nazca fuese anterior a Necrópolis, a base de un examen de los bordados. Ahora se muestra dudoso, aunque no ve razón alguna para suponer Necrópolis como más antigua que la cultura de Nazca.

Concluye también que no, puede ya contrastar Cavernas y Nazca con la cultura de la Necrópolis, y que los tres estilos están relacionados básicamente, pero piensa que debemos esperar evidencias antes de decidir sobre el orden cronológico de Necrópolis y Nazca. Estas dos últimas culturas difieren en que Necrópolis está bien localizada en tiempo y espacio, mientras que Nazca se desparrama en los valles de lca y Río Grande en sus formas $A$ y $B$ supuestas incipiente y madura respectivamente. En su fase Y, mezclada, se extiende al Sur hasta Majes; al Norte, hasta Cañete; al Interior hasta Huari. El estilo de la Necrópolis parece agónico. El de Nazca se prolonga a lo largo de variados cursos y deja influencias múltiples.

En el Apéndice se trata de la historia y distribución de los recipientes con pico, puente y cabeza, corriente post-Chavín y no de origen Chavín, y que va hacia el norte más bien que en dirección sur. Aparece, este rasgo, en Salinar, Virú-Negativo-Gallinazo, Récuay, Wilka- 
wain en una época que el autor llama "post-Chavín temprana", y, subsecuentemente, en Huari-Tiahuanacoide, Lambayeque-Abigarrado-Cursivo Modelado, y Chimú y Chimoide.

El rasgo pico, puente y figura (figura escultórica humana, de ave, de cactus, etc. en lugar de cabeza) está fuertemente representado en post-Cupisnique y pre-Mochica: sobre recipiente único en Salinar, sobre único y doble recipiente en Virú-Gallinazo y Recuay. Por contraste, desaparece casi por completo en la cerámica mochica.

Después de los tiempos mochicas, el pico-puente- y -figura se hizo de nuevo en el norte del Perú, en el estilo Tiahuanaco Costeño (Huari-Norteño), Huari-Lambayeque ( Abigarrado, Cursivo Modelado), y Chimú. Se encuentran en huacos de recipiente único, y en los de recipiente doble, y de igual modo que el doble pico, forma dominante en el Sur en la época Chavín y de Nazca, y que parece haber sido llevada al Norte por la corriente de influencia Huari y Tiahuanacoide. Cuando este primer surgimiento se debilita, se restablece el auge del gollete-estribo en la época Chimú tan dominantemente como en los tiempos mochicas.

Todo el trabajo es un análisis del complejo histórico de interrelaciones del gollete-estribo, el doble pico, la figura (o cabeza) de un único recipiente, y la forma de doble recipiente; relaciones tipológicas basadas en el elemento pico tubular. Indudablemente, esto significa también relaciones históricas. Aunque las interrelaciones son complicadas, hay suficiente evidencia para delinear los eventos con bastante claridad.

\section{Biblioteca de Letras "Jorge Puccinelli Converso"}

